\section{A serological and molecular investigation of American cutaneous leishmaniasis in dogs, three years after an outbreak in the Northwest of Paraná State, Brazil}

\author{
Investigação sorológica e molecular da leishmaniose \\ tegumentar americana em cães, três anos após um \\ surto, no Noroeste do Estado do Paraná, Brasil
}

Gustavo Kiyoshi Massunari 1

Evandra Maria Voltarelli 2

Demilson Rodrigues dos Santos 3

Ademar Rodrigues dos Santos 3

Luiz Paschoal Poiani ${ }^{3}$

Otílio de Oliveira ${ }^{3}$

Raul Jorge Violato ${ }^{3}$

Ricardo Matsuo 4

Ueslei Teodoro 1

Maria Valdrinez Campana Lonardoni 1

Thaís Gomes Verzignassi Silveira 1

\section{Introduction}

1 Universidade Estadual de Maringá, Maringá, Brasil.

2 Centro de Controle de

Zoonoses, Maringá, Brasil.

$315 \underline{a}$ Regional de Saúde.

Secretaria de Saúde do

Paraná, Maringá, Brasil.

4 Secretaria Estadual de

Saúde, Curitiba, Brasil.

Correspondence

T. G. V. Silveira

Departamento de Análises Clínicas, Universidade

Estadual de Maringá.

Av. Colombo 5790, Maringá, $P R$

87020-900, Brasil.

tgvsilveira@uem.br

\begin{abstract}
Classic and molecular (polymerase chain reaction - PCR) techniques were used to diagnose American cutaneous leishmaniasis in 149 dogs from an area in the northwest of Paraná State, Brazil, where an American cutaneous leishmaniasis outbreak occurred in 2002. The results were compared to a set of previously obtained results. Twenty-five dogs had positive indirect immunofluorescence (IIF) (titers $\geq 40$ ), including two animals with suggestive lesions. The percentage of dogs with positive IIF was similar to that found in a previous study. The cultures of the lesion, blood and bone marrow were negative for Leishmania. A direct search for the parasite in the lesions proved negative, although PCR tests were positive. The PCR did not detect the DNA of Leishmania (Viannia) in the blood, even for those that had positive PCR in a previous study. The follow up of the 27 dogs showed that the majority of them had maintained the same levels of antibodies that had been detected previously. There was a reduction in the number of dogs with lesions, probably due to the transmission control measures that were adopted after the outbreak.
\end{abstract}

Cutaneous Leishmaniasis; Dogs; Serology
Leishmaniasis is a serious public health problem across the world, with approximately 350 million people living under the risk of contracting one of the forms of the disease. It is estimated that there are 12 million cases of leishmaniasis in 88 countries, 72 of them developing countries, and an annual growth of 1.5 million new cases 1 . Around $90 \%$ of cases of cutaneous leishmaniasis occur in Iran, Afghanistan, Syria, Saudi Arabia, Brazil and Peru, and more than $90 \%$ of cases of visceral leishmaniasis occur in Bangladesh, Brazil, India and the Sudan 1

In Brazil, the prevalence of American cutaneous leishmaniasis has been increasing in every state for the last 20 years, with an annual occurrence of 20,000-25,000 cases since $1987^{2}$. In the period from 1980 to 2005 , of the 13,486 cases registered in the southern region of the country, $13,316(98.7 \%)$ occurred across the north and west of the state of Paraná 3,4 , showing the endemic nature of the disease, which attacks people of both sexes and from all age ranges 5 .

Despite the fact that American cutaneous leishmaniasis was originally associated with forest environments, urbanization and deforestation have led to an adaptation of the transmission cycle to the peri-domiciliary environment 6 . In American cutaneous leishmaniasis-endemic areas, it has become common to encounter infected dogs 7 , which suggests that they can serve 
as reservoirs of Leishmania 6 . The circumstantial evidence that suggests that dogs act as hosts of American cutaneous leishmaniasis is based on the fact that Leishmania isolates from humans and dogs are identical, and that the risk of infection in dogs correlates with the risk of infection in humans 6. In Brazil, natural infections of domestic dogs by L. (Viannia) braziliensis have been documented in regions affected by the periurban transmission of cutaneous leishmaniasis 8 . In the northwest region of the state of Paraná, both dogs infected with $L$. (V.) braziliensis 9,10 and dogs with positive serology for American cutaneous leishmaniasis 11,12 have been detected.

Serological tests are used in epidemiological studies to detect infected dogs. As American cutaneous leishmaniasis is often asymptomatic in these animals, clinical and parasitological methods of diagnosis lack sensitivity ${ }^{6}$. However, the sensitivity and specificity of serological tests vary considerably, and it is believed that they underestimate the true prevalence of the disease. The polymerase chain reaction (PCR) technique is starting to be used as an extra diagnostic tool for canine American cutaneous leishmaniasis 13 and has proved to be more sensitive than other diagnostic methods, including culture, direct search and inoculation into hamsters 14

The aim of this paper is to carry out an epidemiological investigation into American cutaneous leishmaniasis in dogs living in a rural settlement in the northwest of the State of Paraná, three years after an outbreak of the disease in humans and dogs, and to compare the data to that obtained in studies carried out previously in the same area.

\section{Materials and methods}

\section{Area of study}

The study was carried out in the rural settlement of Nossa Senhora Aparecida and in the district of São Luiz, located in the municipality of Mariluz (2400' S and 5310' W), in the Northwest Mesoregion of Paraná State, Brazil, which has an area of $391.53 \mathrm{~km}^{2}$, an altitude of 500 meters and is $594 \mathrm{~km}$ from Curitiba, the state capital. It has a humid mesothermic subtropical climate, with a mean temperature of $22^{\circ} \mathrm{C}$ in the summer and less than $18^{\circ} \mathrm{C}$ in the winter.

\section{Design of the study}

The rural settlement is divided into 256 lots, and all dogs from 68 lots were included in the study according to the following criteria: (a) lots where confirmed cases of human and canine American cutaneous leishmaniasis had occurred, (b) lots close to remaining forest reserves and (c) dogs with lesions. The study was carried out in July 2005.

For every house visit, an epidemiological index card relating to each animal was filled out. The information on the card included the owner's name and address, and information about their dogs (origin, length of residence, sex, breed, approximate age, previous examinations and type of material collected). Each owner was informed about the objectives of the research, and those that agreed to participate signed terms of free and informed consent.

The study protocol was submitted to the Committee for Ethical Conduct in the Use of Animals in Experiments (CEAE) at the State University of Maringá, and approved according to report 027/2005 on 17/May/2005.

\section{Biological material}

The animals were restrained and anesthetized so that biological material could be collected by veterinary practitioners who were part of the research team.

For the collection of lesion and bone marrow material, anesthesia with dissociative drugs (10\% ketamine - 15mg/kg/IM and 20\% Xylazine - 1$2 \mathrm{mg} / \mathrm{kg} / \mathrm{IM}$ ) and local anesthesia with $0.2 \%$ lidocaine (diluted to 1:10) was carried out.

Some of the biological material (biopsies and scrapes of the inside edge of the lesion and bone marrow) was used for the parasite search and some was stored in micro tubes containing $100 \mu \mathrm{L}$ STE buffer (0.1M NaCl; 10mM TRIS, pH 8.0, $1 \mathrm{mM}$ $\mathrm{Na}_{2}$ EDTA. $2 \mathrm{H}_{2} \mathrm{O}, \mathrm{pH} 8.0$ ) and maintained at $-18^{\circ} \mathrm{C}$ prior to DNA extraction.

Approximately $5 \mathrm{ml}$ of blood was collected from each animal. An aliquot of $2 \mathrm{ml}$ of blood was added to an equal volume of ACD solution (25mM citric acid; $50 \mathrm{~mm}$ sodium citrate; $81 \mathrm{mM}$ glucose), and the leukocyte layer was separated and stored at $-18^{\circ} \mathrm{C}$ until DNA extraction. The rest of the blood was used for parasite searches and for obtaining serum, which was stored at $-18^{\circ} \mathrm{C}$ until use.

\section{Parasite search}

Slides containing smears of the biopsies, scrapes from the lesions and bone marrow were stained with Giemsa, and a direct search (DS) for Leishmania amastigote forms was carried out under a common optical microscope.

Blood and bone marrow samples were cultivated in BBA medium (Blood Base Agar - BBL) 15 
supplemented with $10 \%$ defibrinated rabbit blood and antibiotics (100UI/mL penicillin and $100 \mu \mathrm{g} / \mathrm{ml}$ Streptomycin) and incubated at $25^{\circ} \mathrm{C}$. The cultures were analyzed weekly for the presence of promastigote forms of Leishmania. Every 15 days, the supernatant of the culture was transferred to a new culture medium.

\section{Indirect immunofluorescence reaction}

For the antibody search, promastigote forms of L. (V.) braziliensis and anti-dog immunoglobulin $\mathrm{G}$ conjugated to fluorescein (Sigma) were used, with titers $\geq 40$ being considered as a positive result 11 . The samples that were considered positive were analyzed for the presence of anti-Trypanosoma cruzi antibodies by indirect immunofluorescence reaction (IIF), using the Imunocruzi antigen (Biolab, Rio de Janeiro, Brazil) and anti-dog immunoglobulin $\mathrm{G}$ conjugated to fluorescein (Sigma).

\section{Polymerase Chain Reaction}

To extract the DNA from the leukocyte layer, the guanidine-phenol method 16 , with modifications, was used. The sample was centrifuged $(3,500 \mathrm{~g}$, $15 \mathrm{~min}$ ) and the sediment washed with PBS. Three hundred microliters of guanidine-phenol isothiocyanate solution and $50 \mu \mathrm{l}$ of chloroform were added to the sediment. After centrifugation $(9,300 \mathrm{~g}, 10 \mathrm{~min})$, the supernatant was transferred to tubes containing $300 \mu \mathrm{l}$ of absolute ethanol and centrifuged again $(9,300 \mathrm{~g}, 15 \mathrm{~min})$. The sediment was then washed with $300 \mu \mathrm{L}$ of absolute ethanol, $(9,300 \mathrm{~g}, 10 \mathrm{~min})$ and dried in a dry bath (BIOPLUS IT -2002 , Brazil) at $95^{\circ} \mathrm{C}$. The sediment was rehydrated in $50 \mu \mathrm{L}$ of TE buffer (10mM TRIS; $1 \mathrm{mM}$ $\mathrm{Na}_{2}$ EDTA. $\mathrm{H}_{2} \mathrm{O}, \mathrm{pH}$ 8.0).

The extraction of the DNA from the lesion biopsy was carried out using the Puregene ${ }^{\circledR}$ kit (Gentra, USA). The DNA from the lesion-scrape samples was extracted by incubation at $95^{\circ} \mathrm{C}$ for 30min in a Personal Cycler Thermocycler (Biometra, Germany), followed by centrifugation $(13,000 \mathrm{~g}, 1 \mathrm{~min})$ in order to obtain the supernatant.

The DNA from the bone marrow samples was extracted by the guanidine-phenol 16 and the phenol-chloroform 17 methods.

All the DNA samples were stored at $4^{\circ} \mathrm{C}$ until amplification.

The primers MP1L (5' - TAC TCC CCG ACA TGC CTC TG - 3') and MP3H (5' - GAA CGG GGT TTC TGT ATG C - 3') were used for amplification, as described by Lopez et al 18, which amplify a $70 \mathrm{bp}$ fragment of the kDNA region of the members of the $L$. (V.) subgenus. The reaction medium
$(25 \mu \mathrm{L})$ was composed of $1 \mu \mathrm{M}$ of each of the primers (Invitrogen), 0.2mM dNTP (Invitrogen), $3 \mathrm{mM}$ $\mathrm{MgCl}_{2}$ (Invitrogen), $1 \mathrm{U}$ Taq DNA polymerase (Invitrogen) in enzyme buffer (1x) and $2 \mu \mathrm{L}$ of the DNA sample. A positive $(2 \mu \mathrm{L}$ DNA extracted by boiling the promastigote forms of $L$. braziliensis) and a negative $(2 \mu \mathrm{L}$ ultra pure water) amplification control were used. The amplification was carried out in a Personal Cycler Thermocycler (Biometra, Germany) with an initial temperature of $95^{\circ} \mathrm{C}$ for $5 \mathrm{~min}$. Then, 35 cycles were carried out, separated into three stages: denaturing $\left(95^{\circ} \mathrm{C}-1.5 \mathrm{~min}\right)$, annealing $\left(55^{\circ} \mathrm{C}-1.5 \mathrm{~min}\right)$ and extension $\left(72^{\circ} \mathrm{C}-2 \mathrm{~min}\right)$. Afterwards, the micro tubes were kept at $72^{\circ} \mathrm{C}$ for $10 \mathrm{~min}$, cooled and kept at $4^{\circ} \mathrm{C}$ until use. The amplified samples were submitted to electrophoresis in 3\% agarose gel, containing $0.1 \mu \mathrm{g} / \mathrm{mL}$ ethyl bromide, at $10-15 \mathrm{~V} /$ $\mathrm{cm}$ for 20min. The presence of bands was verified in a transilluminator (Macro Vue UV-20, Hoefer, USA).

\section{Results}

Of the 149 dogs studied, 104 (69.8\%) were male and $45(30.2 \%)$ female. The average age of the dogs was seven, varying from three months to 15 years. Of these animals, 134 were from the rural settlement of Nossa Senhora Aparecida and 15 from the district of São Luiz. Of the 146 serum samples analyzed by IIF, 25 (17.1\%) had titers 40 (Table 1). All of the positive samples were from dogs from the Nossa Senhora Aparecida rural settlement.

Two animals (1.3\%) from Nossa Senhora Aparecida had suspected American cutaneous leishmaniasis lesions on the scrotum. Parasite searches in the lesions of the two animals were negative. However, the PCR (for both biopsies and scrapes) detected the DNA of Leishmania (Viannia) in both. These animals had anti-Leishmania antibody titers of 80 and 320 (Table 1). The search for anti-Tr. cruzi antibodies revealed lower titers to those encountered for L. braziliensis (titers of 40 and $<20$, respectively).

Of the 144 dogs without lesions, 23 (16.1\%) showed antibody titers $\geq 40$ in the IIF for Leishmania (Table 1). In the search for anti-Tr. cruzi antibodies, two of these animals had titers equal to or lower than those encountered for Leishmania braziliensis (titers 20 and 40).

The blood cultures (54 animals) and the blood PCR results (149 animals) were negative, including the two dogs with lesions. For the bone marrow samples, the Leishmania sp. direct search (58 animals), culture (43 animals) and PCR (60 animals) were also negative. 
Distribution of the results of the indirect immunofluorescence reaction for American cutaneous leishmaniasis in 146 dogs from the Municipality of Mariluz, Paraná State, Brazil, 2005.

\begin{tabular}{|c|c|c|c|c|c|c|c|c|c|c|c|c|c|}
\hline & \multirow[t]{3}{*}{$\mathbf{N}$} & \multicolumn{12}{|c|}{ Anti-Leishmania antibodies (titers) } \\
\hline & & \multicolumn{2}{|c|}{$<20$} & \multicolumn{2}{|c|}{20} & \multicolumn{2}{|c|}{40} & \multicolumn{2}{|c|}{80} & \multicolumn{2}{|c|}{160} & \multicolumn{2}{|c|}{320} \\
\hline & & $\mathbf{n}$ & $\%$ & n & $\%$ & n & $\%$ & n & $\%$ & n & $\%$ & n & $\%$ \\
\hline Dogs with lesion & 2 & - & - & - & - & - & - & 1 & 50.0 & - & - & 1 & 50.0 \\
\hline Dogs without lesion & 144 & 36 & 25.0 & 85 & 59.0 & 20 & 13.9 & 3 & 2.1 & - & - & - & \\
\hline Total & 146 & 36 & 24.7 & 85 & 58.2 & 20 & 13.7 & 4 & 2.7 & - & - & 1 & 0.7 \\
\hline
\end{tabular}

n: number of dogs.

In Table 2 the results of this investigation are compared with those of the investigations carried out in the same location in 200210 and 2003 19. In 2002, 2003 and 2005, there were 15.9\%, 27.3\% and $1.3 \%$ dogs with suspected American cutaneous leishmaniasis lesions, respectively. The proportion of dogs with positive serology was similar for the three years studied: $19 \%, 19.3 \%$ and $17.1 \%$ in 2002, 2003 and 2005, respectively.

An analysis of the epidemiological index cards showed that 27 of the dogs in this study had been included in the previous studies. Of four animals that had lesions (positive DS and/or PCR) in 2002/2003, two still had active lesions and two had healed lesions. With regard to serology, 18 (66.7\%) of the animals continued to have titers $<40$, three $(11.1 \%)$ continued to have titers $\geq 40$, three (11.1\%) had increased their levels to have titers $\geq 40$ and three (11.1\%) had reduced their levels to have titers 20 .

\section{Discussion}

In the State of Paraná, American cutaneous leishmaniasis has been registered in 276 of its 399 municipalities, presenting a wide and irregular distribution, with a concentration of cases in municipalities located in the north and west, coinciding with areas that have a high degree of destruction of native vegetation due to agricultural exploitation for the growing of monocultures and creation of pastures 4 .

This study was carried out in an endemic area in the northwest of the state, where the causal agent of the human and canine infection is $L$. (V.) braziliensis 10. The first cases of American cutaneous leishmaniasis in the rural localities of the Nossa Senhora Aparecida settlement, Fazenda Santa Gertrudes and Povoado São Luís, in the municipality of Mariluz, occurred at the end of December 2001, and the outbreak started in March 200210.

In the present investigation, only two of the dogs (1.3\%) had American cutaneous leishmaniasis, a lower proportion than in the previous studies 11,19 . None of these animals had a positive DS, even though in 2003 Velásquez et al. 19 encountered $12.8 \%$ of animals with positive DSs for Leishmania. It must be stated that the lesions of these two dogs were old, which justifies the negative result in the DS, whose sensitivity diminishes with the evolution of the lesion 20 . The cultures of the lesion materials (biopsy and scrape) were also negative. Sensitivity in the detection of the parasite depends on the amounts of the parasite 21 and on the evolution time of the lesions caused by $L$. braziliensis 22 . The low sensitivity of the parasite search may be a consequence of a lack of parasites in the lesions, in the case of canine American cutaneous leishmaniasis 23 . and of the irregularity in the distribution of the parasite in cutaneous lesions 24 .

The percentage of dogs with positive serology was similar to that found in the previous studies. Despite the fact that dogs that were reactive in serological techniques were considered as being infected, considering that the absence of suspected lesions in dogs from endemic areas of human American cutaneous leishmaniasis does not signify the absence of canine infection 25 , the possibility that the positive serology of the dogs is a consequence of past infection should not be discarded. The positive serology in dogs from endemic areas has been reported by various researchers 6,11,12,19. Madeira et al. 26 suggest periodic follow-ups of dogs in endemic areas, or those areas whose landscape could maintain the parasitic cycle, in order to confirm their diagnosis.

Molecular methods based on PCR are useful tools in the detection of the infection and in the 
Results obtained in the direct analysis, indirect immunofluorescence and polymerase chain reaction (PCR) for American cutaneous leishmaniasis in dogs from the Municipality of Mariluz, Paraná State, Brazil, 2002, 2003 and 2005.

\begin{tabular}{|c|c|c|c|c|c|c|}
\hline & \multicolumn{2}{|c|}{2002 * } & \multicolumn{2}{|c|}{$2003 * \star$} & \multicolumn{2}{|c|}{2005} \\
\hline & $\mathrm{P} / \mathrm{N}$ & $\%$ & $\mathrm{P} / \mathrm{N}$ & $\%$ & $\mathrm{P} / \mathrm{N}$ & $\%$ \\
\hline Dogs with suggestive lesions of American cutaneous leishmaniasis & $20 / 126$ & 15.9 & $39 / 143$ & 27.3 & 2/149 & 1.3 \\
\hline Direct search for parasite in the lesion & $6 / 20$ & 30.0 & $5 / 39$ & 12.8 & $0 / 2$ & 0.0 \\
\hline Indirect immunofluorescence reaction & $24 / 126$ & 19.0 & $27 / 140$ & 19.3 & $25 / 146$ & 17.1 \\
\hline PCR in lesion & - & - & $17 / 39$ & 43.6 & $2 / 2$ & 100.0 \\
\hline PCR in blood & - & - & $26 / 139$ & 18.7 & $0 / 149$ & 0.0 \\
\hline
\end{tabular}

P: number of positive animals; $\mathrm{N}$ : number of animals.

* Lonardoni et al. 10;

** Velásquez et al. 19

identification 27 of Leishmania in clinical samples 18,28 or in purified DNA 29,30. Velásquez et al. 19 using the same primers as used in this study, reported that the PCR was capable of detecting $0.9 \mathrm{fg}$ of DNA or 3.2 parasites/ $\mu \mathrm{L}$, findings similar to those reported by Lopez et al. 18 The PCR was positive in the two animals that had lesions, for both the lesion biopsies and scrapes, thus showing a higher sensitivity than DS. PCR is therefore useful in the diagnosis of infection by Leishmania (Viannia) as the number of parasites in the clinical samples is low 18,31 .

Analyzing the data presented in this study, it can be seen that no single technique alone was capable of determining the true prevalence of canine American cutaneous leishmaniasis in the region studied, as by using only DS, for example, the dogs with suspected lesions would not have had a confirmed diagnosis. Using only PCR, only the animals with suspected lesions would have been diagnosed. On the other hand, the isolated use of serological tests in routine analysis is limited due to the occurrence of false-positive results, through the possibility of cross-reactions with other pathogens. Reithinger et al. 32 suggested that epidemiological studies of dogs and humans should be carried out through the association of serological and PCR tests in order to determine the true extension of subclinical infections in areas where American cutaneous leishmaniasis is endemic.

Even though this investigation did not detect Leishmania or the DNA of L. (Viannia) in the blood and bone marrow of the dogs, even in the two animals that had lesions, there are reports of the presence of Leishmania DNA in the blood 13,14,19,32,33 and bone marrow 14,32 of dogs in ACL-endemic areas. Previously, Velásquez et al. 19 found, in the same area of study, the DNA of $L$.
(Viannia) in the blood of animals, corroborating the studies of Reithinger et al. 13,14,32 and supporting the hypothesis that dogs can act as secondary reservoirs of American cutaneous leishmaniasis. According to Weigle et al. ${ }^{34}$ L. (Viannia) primarily locates itself at the site of infection on the skin and subsequently disseminates itself hematogenously, which happens over an undetermined time interval. It should be remembered that Velásquez et al.'s 19 study was carried out soon after the occurrence of an outbreak of American cutaneous leishmaniasis, in both humans and dogs, indicating the wide circulation of the parasite in the region at that time. The negativity of the PCR tests on the blood of the animals in this study could indicate that, with the evolution of the disease, the hematogenous dissemination may have already been controlled by the immune system, reducing the importance of the role of the dog in the transmission cycle of the parasite.

The follow-up of some animals after the outbreak shows that the $33.3 \%$ of them continue to have significant antibody titers, indicating the maintenance of the subclinical infection. The smaller number of dogs with American cutaneous leishamaniasis lesion and the absence of other dogs with recent lesions indicate a reduction in the transmission level of Leishmania in the region.

The reduction in the number of dogs with American cutaneous leishamniasis, compared to the previous investigations, is probably due to the measures adopted for the control of the transmission. After the outbreak that occurred in $2001 / 2002$, houses were moved at least $50 \mathrm{~m}$ from the forest (a forest reserve of approximately $121,000 \mathrm{~km}^{2}$ ), shelters for domestic animals such as cattle, pigs and chickens were constructed in between the houses and the forest, with the aim 
of acting as a zooprophylactic barrier, and the residents were instructed to avoid hunting in the forest and maintain cleanliness in areas around their dwellings (removal of organic matter such as leaves, fallen fruits, animal feces and food leftovers). Since 2003, no cases of human American cutaneous leishmaniasis have occurred (Mariluz Health Department) and in this study, no dogs with recent infections were found. It remains to be seen if the existence of dogs with positive serology and old lesions, in which no circulating parasites were detected, has a role in the maintenance of the endemicity of American cutaneous leishmaniasis.

\section{Resumo}

Neste estudo, utilizaram-se técnicas clássicas e moleculares (reação em cadeia da polimerase - PCR) para o diagnóstico da leishmaniose tegumentar americana em 149 cães de uma área no noroeste do Estado do Paraná, Brasil, onde ocorreu um surto de leishmaniose tegumentar americana em 2002; os resultados foram comparados aos obtidos anteriormente. Vinte e cinco cães tiveram a imunofluorescência indireta (IFI) positiva (títulos $\geq 40$ ), incluindo dois animais com lesão sugestiva. O percentual de cães com IFI positiva foi semelhante aos encontrados nos inquéritos anteriores. As culturas dos materiais de lesão, sangue e medula óssea foram negativas para Leishmania. A pesquisa direta do parasito em lesão foi negativa, no entanto a PCR foi positiva. A PCR não detectou DNA de Leishmania (Viannia) no sangue dos cães estudados, mesmo naqueles que tiveram PCR positiva no estudo anterior. O acompanhamento de 27 animais mostrou que a maioria deles permaneceu com os mesmos níveis de anticorpos detectados anteriormente. Houve redução do número de cães com lesões, provavelmente em virtude das medidas de controle da transmissão adotadas após o surto de 2002.

\section{Conclusion}

It can be concluded that: (i) there are still dog carriers of Leishmania (Viannia) lesions among the animals studied; (ii) hematogenous dissemination of the parasite in the dogs was not detected; (iii) the serology test showed that the prevalence of anti-L. braziliensis antibodies remained at the same levels as previously detected in the same locality, which indicates a subclinical infection or past infection in these animals; (iv) the followup carried out in a group of dogs showed that in some of them the lesion may remain active for more than three years; and (v) the adopted infection-control measures seem to have contributed to the control of the transmission of American cutaneous leishmaniasis in the area under study.

The studies carried out to date suggest that dogs have a secondary role in the transmission cycle of the parasite. Follow-ups of dogs in areas where outbreaks of American cutaneous leishmaniasis occurred, such as the region studied in this paper, can contribute to an understanding of this phenomenon.

\section{Contributors}

G. K. Massunari participated in the collection of biological material in the field, in the laboratory tests and in the development of the manuscript. E. M. Voltarelli, R. Matsuo, D. R. Santos, A. R. Santos, L. P. Poiani, O. Oliveira and R. J. Violato contributed towards the conception and design of the study, the collection of biological material in the field and the development of the manuscript. U. Teodoro and M. V. C. Lonardoni contributed towards the data analysis, the development of the manuscript and the final revision of the text. T. G. V. Silveira supervised the study and contributed to the analysis of the data, development of the manuscript and the final revision of the text.

\section{Acknowledgments}

The authors wish to thank the Brazilian Council for Scientific and Technological Development the Paraná State Research Foundation (Araucária Foundation) for providing financial support for this study. The text was translated by Peter Grimshaw. 


\section{References}

1. World Health Organization. Leishmaniasis disease information. http://www.who.int/emc/diseases/ leish/index.html (accessed on 26/Feb/2005).

2. Organización Panamericana de la Salud. La leishmaniasis em las Américas. Bol Epidemiol 1994; 15:8-13.

3. Ministério da Saúde. Leishmaniose tegumentar americana: distribuição de casos confirmados, por Unidade Federada. Brasil, 1980-2005. http:// portal. saude.gov.br/portal/arquivos/pdf/leishmaniose 2006.pdf (accessed on 13/Feb/2007).

4. Lima A, Minelli L, Teodoro U, Comunello E. Distribuição da leishmaniose tegumentar por imagens de sensoriamento remoto orbital, nos Estado do Paraná, Brasil. An Bras Dermatol 2002; 77:681-92.

5. Silveira TGV, Arraes SMAA, Bertolini DA, Teodoro U, Lonardoni MVC, Roberto ACBS, et al. Observações sobre o diagnóstico laboratorial e a epidemiologia da leishmaniose tegumentar americana no Estado do Paraná, sul do Brasil. Rev Soc Bras Med Trop 1999; 32:413-23.

6. Reithinger R, Davies CR. Is the dog (Canis familiaris) a reservoir host of American Cutaneous Leishmaniasis? A critical review of the current evidence. Am J Trop Med Hyg 1999; 61:530-41.

7. Santos GPL, Sanabria A, Marzochi MCA, Santos EGOB, Silva VL, Pacheco RS, et al. Prevalência da infecção canina em áreas endêmicas de leishmaniose tegumentar americana, do município de Paracambi, Estado do Rio de Janeiro, no período entre 1992 e 1993. Rev Soc Bras Med Trop 2005; 38:161-6.

8. Falqueto A, Coura JR, Barros GC, Grimaldi G, Sessa PA, Carias VRD, et al. Participação do cão no ciclo de transmissão da leishmaniose tegumentar no município de Viana, estado do Espírito Santo, Brasil. Mem Inst Oswaldo Cruz 1986; 81:155-63.

9. Lonardoni MVC, Teodoro U, Arraes SMAA, Silveira TGV, Bertolini DA, Ishikawa EAY, et al. Nota sobre leishmaniose canina no noroeste do Estado do Paraná, sul do Brasil. Rev Saúde Pública 1993; 27 : 378-9.

10. Lonardoni MVC, Silveira TGV, Alves WA, MaiaElkhoury ANS, Membrive UA, Membrive NA, et al. Leishmaniose tegumentar americana humana e canina no Município de Mariluz, Estado do Paraná, Brasil. Cad Saúde Publica 2006; 22:2713-6.

11. Silveira TGV, Teodoro U, Lonardoni MVC, Toledo MJO, Bertolini DA, Arraes SMAA, et al. Investigação sorológica em cães de área endêmica de leishmaniose tegumentar no Estado do Paraná, sul do Brasil. Cad Saúde Pública 1996; 12:89-93.

12. Zanzarini PD, Santos DR, Santos AR, Oliveira O, Poiane LP, Lonardoni MVC, et al. Canine American cutaneous leishmaniasis in municipalities of northern Paraná State, Brazil. Cad Saúde Pública 2005; 21:1957-61.

13. Reithinger R, Davies CR. American cutaneous leishmaniasis in domestic dogs: an example of the use of the polymerase chain reaction form mass screening in epidemiological studies. Trans R Soc Trop Med Hyg 2002; 96 Suppl 1:S123-6.
14. Reithinger R, Espinoza JC, Courtenay O, Davies CR. Evaluation of PCR as a diagnostic mass-screening tool to detect Leishmania (Viannia) spp. In domestic dogs (Canis familiaris). J Clin Microbiol 2003, 41:1486-93.

15. Walton BC, Shaw JJ, Lainson R. Observations on the in vitro cultivation of Leishmania braziliensis. J Parasitol 1977; 63:1118-9.

16. Chomcynski P, Sacchi N. Single-step method of RNA isolation by acid guanidinium thiocyanatephenol-chloroform extraction. Anal Biochem 1987; 162:156-9.

17. Sambrook, J, Fritsch EF, Maniatis T. Molecular cloning: A laboratory manual. 2nd Ed. Cold Spring Harbor: Cold Spring Harbor Laboratory Press; 1989.

18. Lopez M, Inga R, Cangalaya M, Echeverria J, Llanos-Cuentas A, Orrego C, et al. Diagnosis of Leishmania using the polymerase chain reaction: a simplified procedure for field work. Am J Trop Med Hyg 1993; 49: 348-356.

19. Velásquez LG, Membrive N, Membrive U, Rodrigues G, Reis N, Lonardoni MVC, et al. PCR in the investigation of canine American tegumentary leishmaniasis in northwestern Paraná State, Brazil. Cad Saúde Pública 2006; 22:571-8.

20. Furtado T. Critérios para o diagnostico da leishmaniose tegumentar americana. An Bras Dermatol 1980; 55:81-6.

21. Padilla AM, Marco DJ, Diosque P, Malchiodi E, Fernández M, Marinconz A, et al. Leishmaniasis tegumentária canina: evolutión de las lesiones y carga parasitaria. Medicina 1999; 59 Suppl 3:S54.

22. Marzochi MCA. Doenças infecto-parasitarias: leishmanioses no Brasil - as leishmanioses tegumentares. J Bras Med 1992; 63:82-104.

23. Marco JD, Padilha AM, Diosque P, Fernandez MM, Malchiodi EL, Basombrio MA. Force infection an evolution of lesions of canine tegumentary leishmaniasis in Northwestern Argentina. Mem Inst Oswaldo Cruz 2001; 96:649-52.

24. Mengistu G, Akuffo KB, Fehninger TE, Negese Y, Nilsen R. Comparison of parasitological and immunological methods in the diagnosis of leishmaniasis in Ethiopia. Trans R Soc Trop Med Hyg 1992; 86:154-7.

25. Barbosa GMS, Marzochi MCA, Massard CL, Lima GPS, Confort EM. Aspectos epidemiológicos da leishmaniose tegumentar americana em cães, no Município de Paraty, estado do Rio de Janeiro, Brasil. Cad Saúde Pública 1999; 15:641-6.

26. Madeira MF, Uchôa CMA, Leal CA, Silva RD, Magalhães CM, Serra CMB. Leishmania (Viannia) braziliensis em cães naturalmente infectados. Rev Soc Bras Med Trop 2003; 36:551-5.

27. Degrave W, Fernandes O, Campbell D, Bozza M, Lopes U. Use of molecular probes and PCR for detection and typing of Leishmania - a mini-review. Mem Inst Oswaldo Cruz 1994; 89:463-9. 
28. Meredith SE, Zijlstra EE, Schoone GJ, Kroon CC, van Eys GJ, Schaeffer KU, et al. Development and application of the polymerase chain reaction for the detection and identification of Leishmania parasites in clinical material. Arch Inst Pasteur Tunis 1993; 70:419-31.

29. Rodgers MR, Popper SJ, Wirth DF. Amplification of kinetoplast DNA as a tool in the detection and diagnosis of Leishmania. Exp Parasitol 1990, 71:267-75.

30. Guevara P, Alonso G, Silveira JF, Mello M, Scorza $\mathrm{JV}$, Anez N, et al. Identfication of new world Leishmania using ribossomal gene spacer probes. Mol Biochem Parasitol 1992; 56:15-26.

31. Aviles H, Belli A, Armijos R, Monroy FP, Harris E. PCR detection and identification of Leishmania parasites in clinical specimens in Ecuador: a comparison with classical diagnostic methods. J Parasitol 1999; 85:181-7.
32. Reithinger R, Lambson BE, Barker DC, Davies CR. Use of PCR to detect Leishmania (Viannia) ssp. in dog blood and bone marrow. J Clin Microbiol 2000; 38:748-51.

33. Reithinger R, Lambson BE, Barker DC, Counihan $\mathrm{H}$, Espinoza JC, González JS. Leishmania (Viannia) ssp. Dissemination and tissue tropism in naturally infected dogs (Canis familiaris). Trans R Soc Trop Med Hyg 2002, 96:76-8.

34. Weigle K, De Dvalos M, Heredia P, Molineros R, Saraiva N. Diagnosis of cutaneous and mucocutaneous leishmaniasis in Colômbia: a comparision of seven methods. Am J Trop Med Hyg 1987; 36:489-96.

Submitted on $05 / \mathrm{Jul} / 2007$

Final version resubmitted on $27 / \mathrm{Feb} / 2008$

Approved on 28/Feb/2008 